\title{
鋼板で補強された鉄筋コンクリート造柱の構造性能 STRUCTURAL PERFORMANCE OF REINFORCED CONCRETE COLUMN WITH STEEL JACKETING
}

\author{
鈴木英之*，西原 寛** \\ Hideyuki SUZUKI and Hiroshi NISHIHARA
}

\begin{abstract}
The bar arrangement method of the column whose hoops were simplified was developed on the grounds that the outer steel plate of RC columns was effective in increasing the bond splitting strength of the main bars which were arranged at the outer side in the direction of column width. The test of RC columns with steel jacketing was carried out in order to verify structural performance. As a result, the shear strength did not decrease even after the yield hinges were formed. Furthermore, there were not many cracks in the column with steel jacketing at the final loading. This performance of the column with steel jacketing did not depend on the type of bar arrangement on condition that the amount of lateral reinforcement was the same. In this paper, both the equations for ultimate strength and load-displacement relation that correspond to the destruction pattern for RC columns were showed.
\end{abstract}

Keywords : Reinforced concrete, Column, Steel jacketing, Ultimate strength, Limit drift angle, Hysteretic characteristic 鉄笳コンクリート, 柱, 鋼板補強, 終局耐力, 限界変形角, 復元力特性

\section{1. はじめに}

鉄筋コンクリート(以下RC)造柱の構造性能を向上させる目的で, 柱の外周部に鋼板を巻き付ける工法がある。外周部に配された鋼板 がコンクリートを拘束することによって，コンクリートの圧縮勒性 が向上し，特に軸力と曲げモーメントが同時に作用する柱部材では 曲げ耐力が大きくなり, 変形性能も良くなる。また, 外周部に配さ れた鋼板がせん断補強材の働きをし, 部材のせん断耐力が大きくな る。このように, 外周部に巻かれた鋼板が柱部材の構造性能を向上 させることは多くの研究例えば3).4)によって明らかにされている。

柱部材に曲げモーメントとせん断力が作用したときに，その終局 耐力を決定させる破壊形式として，曲げ破壊，せん断破壊および付 着割裂破壊の3種類が考えられる。これらの破壊形式に対応する終局 耐力を算出することは部材の構造性能を決定する上で極めて重要な ことである。

鋼板補強されたRC部材のせん断耐力は, 既存鉄筋コンクリート造

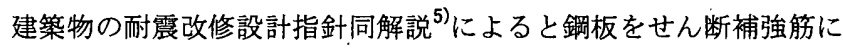
換算し，大野・荒川式をベースとした広沢式によってそのせん断耐 力を安全側に算定できるとしている。しかし，この式はせん断補強 筋の項が平方根で表された実験式であり，必ずしも実際のせん断抵 抗機構を表現しているとは言い難い。また，鋼板補強されたRC部材
をせん断破壊させた実験例は少ないため，鋼板を帯筋に換算する方 法の妥当性についても検証する必要がある。

さらに鋼板補強されたRC部材の付着割裂破壊に対しては, その耐 力を定量的に評価している研究は少なく, 前述の広沢式によってせ ん断破壊との区別が暧昧なまま安全側に評価される場合が多い。こ のように要求された構造性能に対して適正な鋼板厚さを導くための 設計法が確立されているとは言い難く, 必要以上の鋼材量によって 所定の性能を発揮させている例も少なくない。

本論では，まず鋼板補強されたRC造柱部材を対象とし，実際にせ ん断破壊, 付着割裂破壊执よび曲げ破壊する柱の実験を実施し，そ の結果について報告する。併せて外周部の鋼板が隅主笳の付着性能 を向上させるという特徵を生かした配筋法を提案し, その構造性能 を実験により確認する。つぎに鋼板補強されたRC部材に対して，既 報6)で提案した鋼板補強されたRC部材を対象とした主筋の付着割裂 強度算定式と，既往のせん断終局耐力式，および横補強材による拘 束効果を考慮した曲げ終局耐力計算式によって, 破壊形式に応じた 終局耐力の評価が可能であることを示す。さらに鋼板補強された部 材は, 特に部材降伏後の性状が通常のRC部材と異なるという特性を 基にせん断耐力に関する評価法を提案する。，以上より鋼板補強され た部材を対象に, 而力および変形能に関する総合的な評価を試みる。
本論文の一部は参考文献1)2)にて発表している。

* 安藤建設㑣)技術研究所 博士 (工学)

** 安藤建設(侏)技術研究所 室長
Ando Corporation Research Center, Dr. Eng. Manager, Ando Corporation Research Center. 
表1 試験体一覧

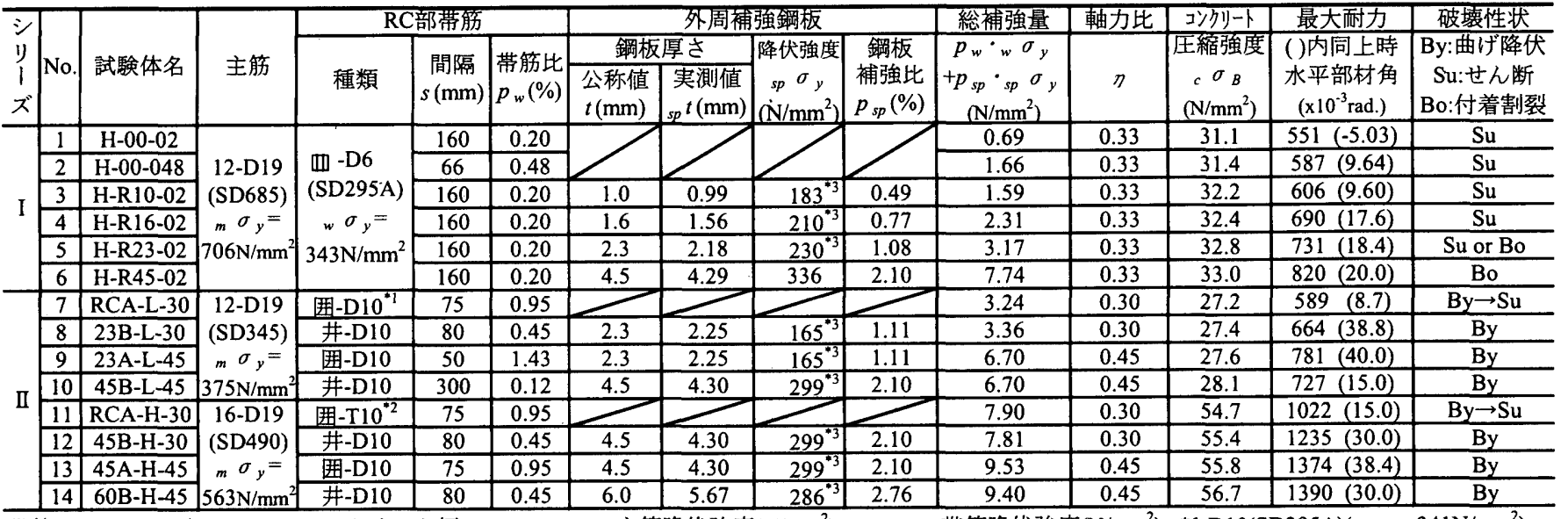

带筋比 $p_{w}=A_{s t} /(s \cdot b) \quad b:$ コンクリート幅 $(\mathrm{mm}) \quad{ }_{m} \sigma_{y}:$ 主筋降伏強度 $\left(\mathrm{N} / \mathrm{mm}^{2}\right)$

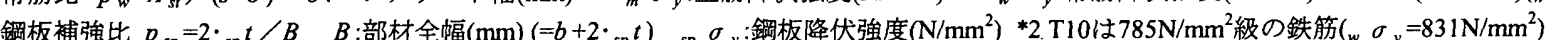

\section{2. 鋼板補強されたRC部材の曲げせん断英験 \\ 2.1 試倹体}

表 1 に試験体一覧，図1に柱試験体形状図を示す。鋼板を含めない 柱の断面は $400 \mathrm{~mm}$ 角であり, 鋼板補強試験体は隅角部において半径 $30 \mathrm{~mm}$ の面取りを施した。鋼板は柱頭, 柱脚部においてスタブとの 間に20mmの隙間を設けた。シリーズ I は部材の曲げ降伏前にせん 断破壊あるいは付着割裂破壊といった脆性的な破壊が生じるように 計画され，主筋は12-D19(SD685)とした。No.1 とNo.2は帯筋のみで横 補強された試験体であり, No.3〜 6は帯筋比をNo.1 と同一とし, 補強 鋼板の厚さを1.0 4.5mmまで変化させた。なおNo.2の帯筋補強試験 体とNo.3の鋼板補強試験体は，鋼板と帯筋による横補強筋量の和 $\left(p_{w} \cdot w \sigma y+p s p \cdot s p \sigma y\right)$ がほぼ等しくなるように計画された。

シリーズIIは部材の曲げ降伏が先行するように計画され，No.7〜 10は主筋をSD345とし, 普通強度のコンクリートを使用した。No.11 〜14の主筋は芯鉄筋を含んだ16-D19(SD490)とし, 高強度コンクリー 卜を使用した。帯筋補強試験体の2体とNo.9およびNo.13は, 帯筋の 形式を外周筋と中子筋が組合わさった，いわゆる「囲」形とした。 No.8,10,12,14の4試験体の帯筋は中子筋だけを組み合わせた「井」形 とし，帯筋と鋼板による横補強筋量の和がそれぞれNo.7,9,11,13とほ ぼ等しくなるように計画された。この「井」形は後述する付着割裂 実験により，部材の外周部に施された鋼板が隅角部に配された主筋 の付着性能を向上させるという特徴を生かした配筇形式である。以

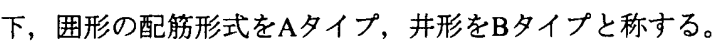

图1中に加力の模式図を示す。本実験は建研式加力により試験体に 軸力と水平力を加えた。本論中でのせん断力 $Q$ は, 図中に示した方 法により, 軸力と水平変位による付加せん断力を加算した值とした。

\section{2 実倹結果}

表1中に実験時の最大耐力と破壊性状を示す。シリーズ Iではいず れの試験体も最終破壊までの間に主筋の降伏は見られず，帯笳補强 試験体はせん断破壊し, 補強鋼板の厚さが増すにつれ破壊形式がせ ん断破壊から付着割裂破壊に移行した。図2に横補強筋量の和がほぼ 等しい試験体同士を重ね合わせたせん断力 $(Q)$-水平部材角 $(R)$ 関倸の 比較を示す。図2aは曲げ降伏前にせん断破壊した帯筋補強試験体と

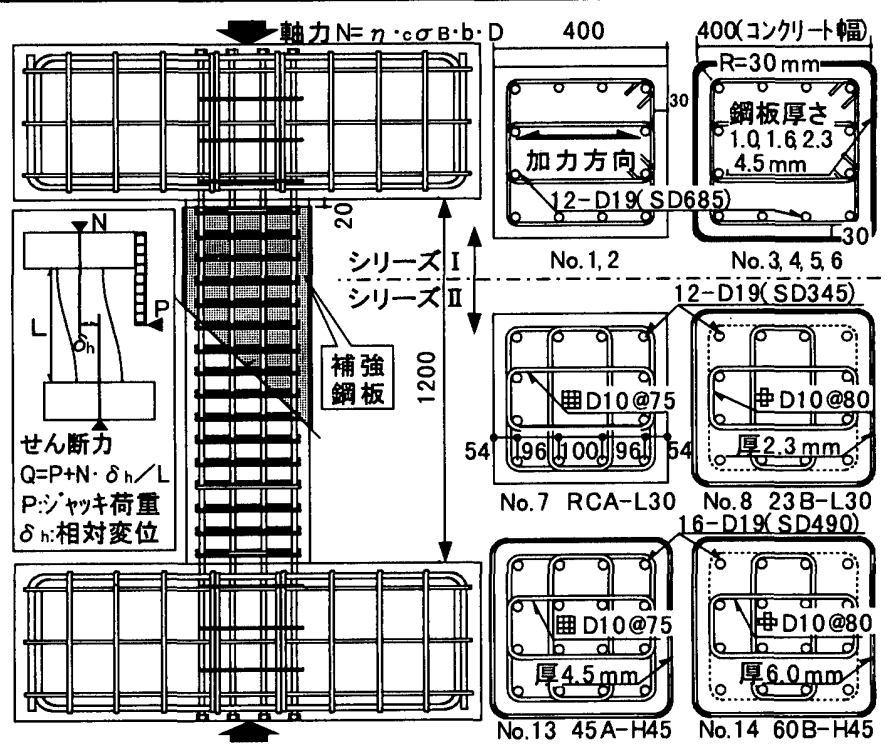

図1柱試験体形状図

鋼板補強試験体の比較であるが，剛性，最大耐力，勒性能ともに差 異は見られない。帯筋と補強鋼板による横補強筋量の和が等しい場 合には，曲げ降伏前のせん断耐力は同等であることが確認された。

一方，図2bは曲げ降伏が先行する部材の比較であるが，部材降伏 時までの剛性には差異が見られなかった。帯筋補強試験体は曲げ降 伏後にせん断破壊したのに対し，鋼板補強試験体は最終加力まで耐 力低下しなかった。写真1にNo.7(RCA-L-30)とNo.8(23B-L-30)の最終 破壊状況を示す。ここで, No.8は実験終了後に鋼板を撤去しひび割 れを観察したものである。鋼板補強試験体は材端部から $150 \mathrm{~mm}$ 以内 の範囲に曲げひび割れが集中しているが，それ以外の区間はひび割 れ幅が0.1 mm以下の軽微なせん断ひび割れが若千発生しているだけ であった。このように曲げ降伏後の性状は, 横補強笳量の和が同等 な場合, 帯笳補強試験体と鋼板補強試験体では大きな差が見られ, 鋼板補強試験体はコンクリートの損傷が極めて小さかった。

図2cは横補強筋量の和がほぼ等しく, 帯笳の配筋形式を変化させ た試験体の比較である。No.14(60B-H-45)は外周帯筋を省略した分, 横補強笳量の和が変化しないように鋼板の厚さを増した試験体であ るが, 最終加力時まで両者の差異は認められなかった。 


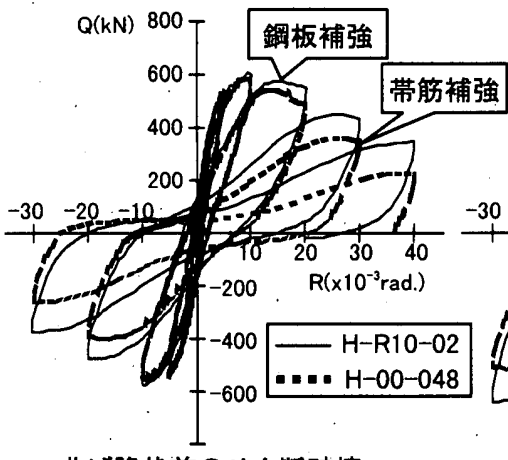

a.曲げ降伏前のせん断破壊

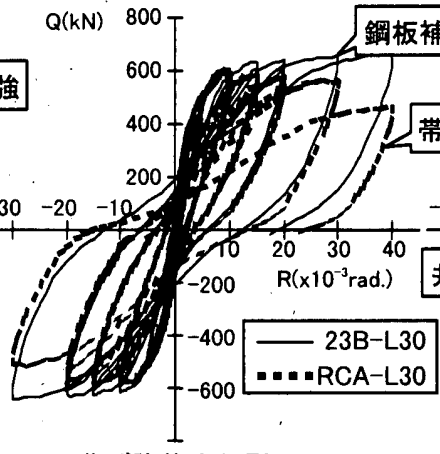

b.曲げ降伏先行型

图2 せん断力 $(\mathrm{Q})$-水平部材角 $(\mathrm{R})$ 関係

\section{3. 終局酎力の検脸}

\section{1 せん断終局耐力}

\section{a. 鋼板補強された部材におけるトラス機構}

図3aに鋼板によるトラス機構の模式図を示す。せん断補強材であ る鋼板と主筋が接していない場合は，図3bに示すように鋼板の隅角 部と主筋の間にC C で示すコンクリート圧縮束が形成されることによ ってトラス機構が成立する。この時, 鋼板には材軸と直交方向の引 張応力が生じる。

次に鋼板が負担するせん断応力を考える。本実験では柱頭, 柱脚 部において鋼板とスタブ間の縁を切っているため, 鋼板自体がせん 断応力を負担するためには内部コンクリートと鋼板の間に材軸方向 の応力伝達が必要となる。鋼板とコンクリート間の付着力を無視す ると，材軸方向の応力伝達は图3cに示すような外周鋼板とコンクリ 一ト間の支圧応力に比例する摩擦力による。この機構が成立する時, 外周鋼板が曲げモーメントとせん断応力を負担するため, 部材の曲 げ剛性およびせん断剛性が高くなることが予想される。しかし，実 験結果を見る限り, 鋼板の有無および厚さによって初期剛性または 降伏時剛性が変化することはなかった。よって外周鋼板は通常の帯 筋と同様に材軸と直交方向の引張応力のみを負担し, 図3aに示した トラス機構によるせん断抵抗機構のみを形成すると考えた。

\section{b. 隅角部における銅板の折り曲げ半径}

図3bにおいて主筋の被り厚さがXY両方向共に等しいとすると,鋼 板降伏時に㧍ける単位長さ当たりの圧縮応力 $C$ c は式(1)で表される。

$$
C_{c}=\sqrt{2} \cdot{ }_{s p} t_{s p} \sigma_{y} \quad(\mathrm{~N} / \mathrm{mm})
$$

ここで, $s p t:$ 補強鋼板の厚さ $(\mathrm{mm}), s p \sigma y:$ 補強鋼板の降伏強度 $\left(\mathrm{N} / \mathrm{mm}^{2}\right)$ である。

益尾らは，鋼板補強された柱部材の軸方向圧縮実験の結果より， 隅角部における鋼板の折れ曲がり部がコアコンクリートを拘束する ことを指摘している77。また, 炭素緎維シートでせん断補強された 柱の曲げせん断実験では, 隅角部の折り曲げ半径を小さくした試験 体に扔いて, 隅角部が局所的に圧壊し, 有効な補強効果が得られな いことを指摘している ${ }^{8)}$ 。そこで，隅角部に扔ける補強鋼板の折り 曲げ半径とコンクリートの支圧強度について考察する。藤井らは主 筋を対象とした $90^{\circ}$ 折り曲げ鉄筋の定着耐力の評価法を提案してお り, その中で, 鉄筇折り曲げ部に扔けるコンクリートの支圧耐力に ついて言及している ${ }^{9)}$ 。ここでは, この折り曲げ鉄筋を補強鋼板に 置き換えて，隅角部におけるコンクリートの支圧耐力の評価を試み

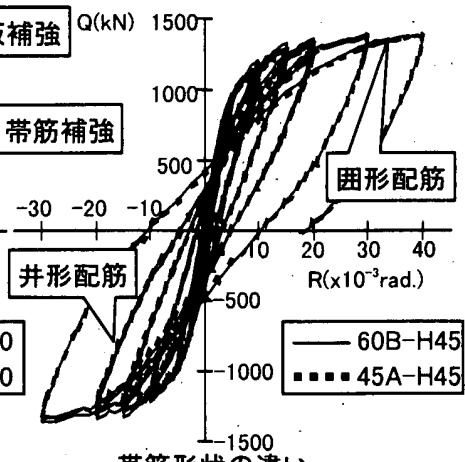
c.帯筋形状の違い

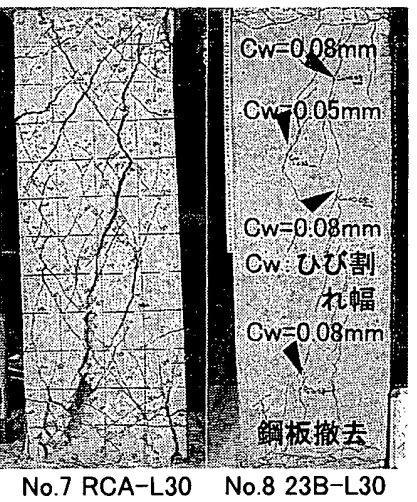
写真1 最終破壊状況

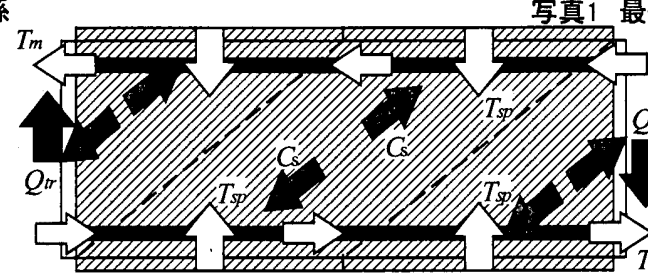

a.鋼板によるトラス機構の模式图

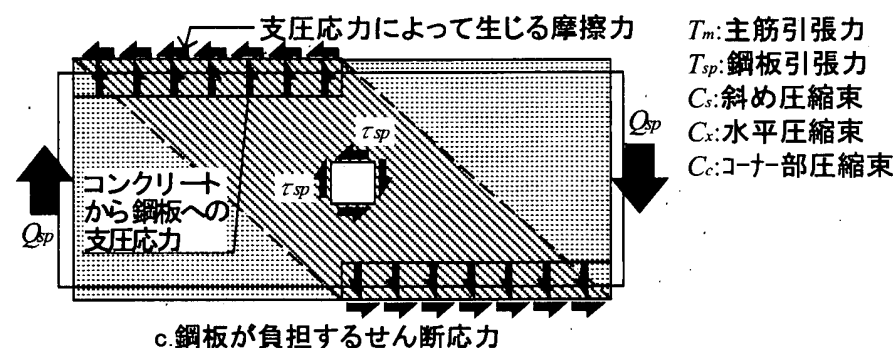

c.鋼板が負担するせん断応力

図3 鋼板によるせん断補強効果

る。つまり，藤井らの提案式を基に鋼板補強の隅角部の支圧耐力に 関連しない倸数を 1 とし, 鉄筋径 $d b$ を補強鋼板の厚さ $s p t$ 抢よび単位幅 (=1)に置き換えると, 鋼板補強された部材の隅角部に扔ける単位長 さ当たりのコンクリートの支圧耐力P $P$ は式(2)で表される。

$$
\begin{aligned}
P_{b} & =k_{0} \cdot k_{1} \cdot k_{2 S} \cdot f_{b o} \cdot \sqrt{2} \cdot r \\
& =0.7 \cdot\left({ }_{c} \sigma_{B} / 39.2\right)^{\alpha} \cdot\{r /(3 \cdot s p)\}^{-0.72} \cdot f_{b o} \cdot \sqrt{2} \cdot r \quad(\mathrm{~N} / \mathrm{mm}) \\
\alpha & =\left\{\begin{array}{ll}
1 / 2 & \left({ }_{c} \sigma_{B}<39.2 \mathrm{~N} / \mathrm{mm}^{2}\right) \\
1 / 3 & \left(39.2 \mathrm{~N} / \mathrm{mm}^{2} \leqq_{c} \sigma_{B} \leqq 118 \mathrm{~N} / \mathrm{mm}^{2}\right)
\end{array}\right\}
\end{aligned}
$$

ここで, $k 0$ : コンクリート強度の影響を表す係数, $k l$ : 折り曲げ 形状の効果を表す係数, $k_{2 S}$ : 鉄筋間のあきから決まる係数(鋼板は連 続しているのであきを零とし， $k_{2 S}=0.7$ となる。), c $\sigma B:$ コンクリー 卜圧縮強度 $\left(\mathrm{N} / \mathrm{mm}^{2}\right), f b 0$ : 基準となるコンクリート支圧強度 $(=187 \mathrm{~N}$ $\left./ \mathrm{mm}^{2}\right), r$ : 隅角部に扔ける鋼板の必要曲げ内法半径 $(\mathrm{mm})$ である。

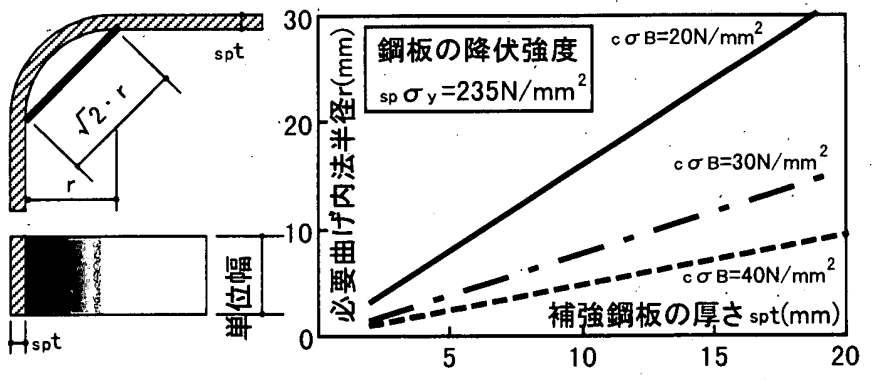

図4鋼板の厚さと必要曲げ内法半径 
鋼板によるせん断補強効果を十分に発揮させるためには，式(1)

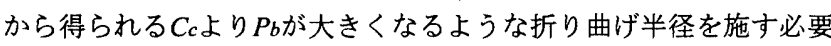
がある。图4に補強鋼板の厚さと必要内法半径の関倸を示す。本実験 の試験体における鋼板の曲げ半径は $30 \mathrm{~mm}$ であり，隅角部の支圧耐 力の観点からすると, 計算から得られる必要曲げ内法半径を十分に 上回っていた。

\section{c. せん断終局耐力計算式}

図3bに示した隅角部の圧縮束 $C_{c}$ が確保されることによって，外周 補強鋼板も通常の帯筋と同様にせん断抵抗要素々なり，曲げ降伏以 前のせん断終局耐力は，帯筇と鋼板の横補強筋量の和 $\left(p_{w} \cdot w \sigma y+p_{s p}\right.$. $s p \sigma y)$ で評価される。本論では，せん断終局耐力を終局強度指針式A 法 $^{10)}$ から算出する。ここで, コンクリート圧縮強度有効係数 $\nu_{0}$ は, 高強度コンクリートへの対応を考慮し, 文献 ${ }^{11)}$ で採用されたCEB式 （式(9)参照）から算出する。また部材のせん断ひび割れ発生以前に はせん断破壊が生じないとすると, 部材のせん断終局耐力 $\left(c Q_{s u}\right)$ は終 局強度指針式A法による計算值 $\left(c Q_{s u A}\right)$ と軸方向応力を考慮した主応 力式によるせん断ひび割れ発生耐力 $(c Q s c)$ のち大きい方となる ${ }^{12)}$

$$
\begin{aligned}
{ }_{c} Q_{s u} & =\operatorname{MAX}\left({ }_{c} Q_{s c},{ }_{c} Q_{s u A}\right) \\
{ }_{c} Q_{s c} & =b \cdot D \cdot \sqrt{\sigma_{t}^{2}+\sigma_{t} \cdot \sigma_{0}} / 1.5 \\
\sigma_{t} & =0.313 \sqrt{{ }_{c} \sigma_{B}}
\end{aligned}
$$

ここで, $b$ : 部材のコンクリート幅 $(\mathrm{mm}), D$ : 部材のコンクリー トせい $(\mathrm{mm}), \sigma 0:$ 軸方向応力度 $\left(\mathrm{N} / \mathrm{mm}^{2}\right)$ である。

\section{2 付着割裂強度}

筆者らは，鋼板補強されたRC部材を対象とし，外周鋼板が主筋の 付着割裂強度に及ぼす影響を実験的に検証した ${ }^{6)}$ 。図5に付着割裂強

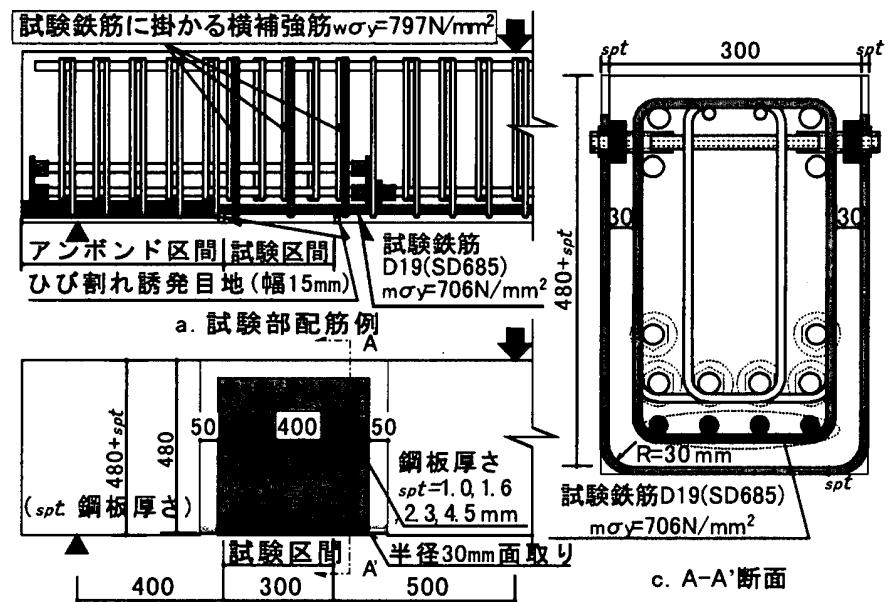

\begin{tabular}{|c|c|c|}
\hline 中子筋 & & 有り, 無し \\
\hline 横補強筋比 & $p_{w}$ & $0,0.32,0.63,0.95,1.43(\%)$ \\
\hline 補強鋼板厚さ & $s p t$ & $\begin{array}{c:c:c:c:}\text { 無L: } 1.0 & 1.6 & 2.3 & 4.5 \\
\end{array}$ \\
\hline 補強鋼板降伏強度 & $s p \sigma_{y}$ & $\begin{array}{c:c:c:c:}183 & 210 & 230 & 336 \vdots\left(\mathrm{N} / \mathrm{mm}^{2}\right) \\
\end{array}$ \\
\hline 総補強竻比 & $p_{w}+p_{s p}$ & $0.32 \sim 3.41 \quad(\%)$ \\
\hline コリクリート圧縮強度 & ${ }_{c} \sigma_{B}$ & $29.4 \sim 32.1$ \\
\hline
\end{tabular}

b. 鋼板補強詿験体形状図

图5 付着割翌強度検証用試験体の形状図

表2 付着割裂強度検証用試験体の要因

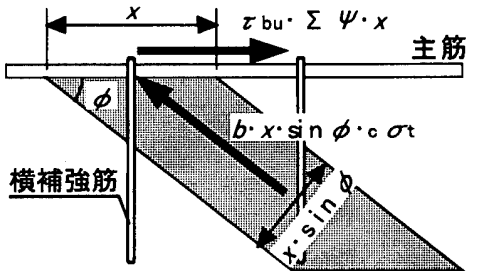

图6 主筋の付着応カで制限されるトラス機構

度検証用の試験体形状図, 表2に同試験体の要因の一筧を示す。図5 に示した試験体は角らの実験 ${ }^{13)}$ を参考とした梁型の形状をしており， U字形の外周鋼板と横補強笳によって補強された梁下端の試験鉄筋 に対して, 最も高い付着忘力が作用し, 試験鉄筋の周囲で付着割裂 破壊が生じるように配筋計画されている。

この実験結果より, 部材の外周部に施された補強鋼板は主筋の付 着割裂強度の上昇に寄与し, その効果は隅角部に配された主筋に対 してより大きくなることが明らかとなった。文献6)では鋼板による 補強効果を取り入れた付着割裂強度算定式を提案している(式(10))。 付着割裂強度時の部材のせん断力 $(c Q b u)$ は, 図6に示すようにトラス 機構が主筋の付着割裂強度で制限されるとして, 式(6)で表される。

$$
\begin{aligned}
&{ }_{c} Q_{b u}= \tau_{b u} \cdot \sum \psi \cdot j_{t} \cdot+\tan \theta \cdot\left(1-\beta_{2}\right) \cdot b \cdot D \cdot v_{0}{ }^{\prime} \sigma_{B} \\
& \tan \theta= \sqrt{(L / D)^{2}+1}-L / D \\
& \beta_{2}= \frac{\left\{\tau_{b u} \cdot \sum \psi /(b \cdot \sin \phi \cdot \cos \phi)\right\}}{v_{0}{ }_{c} \sigma_{B}} \\
& v_{0}= 1.7_{c} \sigma_{B}{ }^{-1 / 3} \\
& \tau_{b u}= \tau_{c o}+\tau_{s t}+\tau_{s p} \\
&= 0.313 \cdot\left\{\left(0.4 b_{s i}+0.5\right)+19 \cdot\left(n_{m} / N+1\right) \cdot q_{s t}\right. \\
&\left.+9.6 \cdot(5 / N+1) \cdot q_{s p}\right\} \cdot \sqrt{c} \sigma_{B} \\
& b_{s i}=\left(b / N \cdot{ }_{m} d_{b}\right)-1 \\
& q_{s t}= \frac{A_{s t}}{s \cdot N \cdot{ }_{m} d_{b}} \quad(12) \\
& \text { ただし, } p_{s p}=\frac{2 \cdot{ }_{s p} t}{b+2 \cdot s p} \leqq 0.0143, \quad \phi=\cot ^{-1}(2.0)=26.6^{\circ}
\end{aligned}
$$

ここで, $\Sigma \psi:$ 鉄筋周長の合計 $(\mathrm{mm}), j_{t}$ : 主筋中心間距離 $(\mathrm{mm})$, $L$ : 部材の内法長さ $(\mathrm{mm}), n m$ : 横補強筋が直接かかる主筋の本数, $N$ : 一列に並んだ主筋の本数, $m d b$ : 主筋の公称径 $(\mathrm{mm}), A s t:$ 一組 の横補強筋断面積 $\left(\mathrm{mm}^{2}\right), s$ : 横補強筋の間隔 $(\mathrm{mm})$ である。

なお，終局時における主筋の存在応力に対する検証は式(14)から 得られる設計用付着応力度 ${ }^{10)}$ と式(10)から得られる付着割裂強度を 比較することで行う。

$$
\tau_{f}={ }_{m} d_{b} \cdot \Delta \sigma /\{4 \cdot(L-d)\} \quad\left(\mathrm{N} / \mathrm{mm}^{2}\right)
$$

ここで, $\Delta \sigma:$ 部材両端部の主筋応力度の差 $\left(\mathrm{N} / \mathrm{mm}^{2}\right), d:$ 部材の 有効せい $(\mathrm{mm})$ である。

\section{3 曲げ終局耐力}

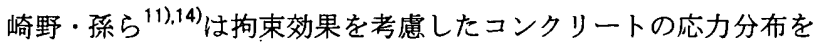
長方形の応力ブロック(以下, 等価応力ブロック)に置換し, 断面圧 縮縁のコンクリートのひずみを与えることで, 容易に断面の曲げ終 局耐力を算出する方法を提案している。計算上の仮定条件として, コンクリートの引張強度を無視し, 鉄筋のひずみは中立軸からの距 
離に比例し，鉄筋の応力歪み関係は圧縮引張ともに完全弾塑性とし ている。これらより，断面の軸方向力の釣り合いを計算し，中立軸 位置と断面の負担曲げモーメントが算出される。

拘束コンクリートの忘力ひずみ関係は崎野・孫らが提案している モデル ${ }^{15)}$ を参考にする。これは横補強材に帯筋または外周鋼板が単 独で使用されているものを対象としている。本実験の試験体も含め て，例えばRC造の既存柱の外周部を鋼板で耐震補強する場合は，横 補強材として鋼板と帯筋が併用される。山川らは横拘束材として正 方形鋼管と帯筋を併用した柱の軸圧縮強度は，両者の効果を単純に 累加することで評価できるとしている ${ }^{16)}$ 。一方で本実験のBタイプ (井形)のように横補強材を中子筇と鋼板とした柱は，同じ横補強筋 量であればAタイプ(囲形)のように外周帯筋, 中子筋および鋼板で拍 束した柱よりも若干軸圧縮強度と勒性が向上する ${ }^{177}$ としている。

ここでは，横補強材として帯筋と鋼板が併用されたコンクリート の拘束効果の評価法として，崎野・孫が提案しているモデルを基に， 各変数の入力方法を修正し, 柱部材の曲げ終局耐力の算出を試みる。 拘束コンクリートの強度上昇率Kは式(15)から算出する。

$$
\begin{gathered}
K=1+\sum_{i=1}^{n} \kappa_{i} \alpha_{i} \cdot \sum \rho_{h} \cdot \sigma_{h y} /{ }_{c} \sigma_{B} \\
\kappa_{i}=11.5 \cdot\left(\frac{d_{i}{ }^{\prime \prime}}{C_{i}}\right) \cdot\left(1-\frac{s_{i}}{2 D_{c i}}\right) . \\
\alpha_{i}=A_{i} / A_{c} \\
\sum \rho_{h} \cdot \sigma_{h y}=\rho_{s p} \cdot s p \sigma_{y}+\rho_{w^{\prime}}{ }_{w} \sigma_{y}
\end{gathered}
$$

ここで, $\rho s p:$ 外周鋼板の体積比, $\rho_{w}$ : 帯筋の体積比, $n:$ 横補 強材の種類数， $d^{\prime \prime}, C, s, D$ cはそれぞれ，带筋の径または鋼板の厚 さ, 横補強材の有効横支持長さ, 帯筋の間隔, 周辺横補強笳の中心 間距離 $(\mathrm{mm}), A i$ : 範囲 $i$ の面積 $\left(\mathrm{mm}^{2}\right), A_{c}$ ：鋼板を含まない柱断面積 $\left(\mathrm{mm}^{2}\right)$ である。

式（18）は横補強材の体積比と降伏強度の積の和である。ここで, 鋼板の体積比は鋼板を含んだ全断面積に対する鋼板の割合，帯筋の 体積比はコンクリート断面に対する帯筋の割合とし，鋼板と帯筋が 併用される場合は，各横補強材の体積比にそれぞれの降伏強度を乗 じたものの和とした。ただし，横補強材の降伏強度は文献 ${ }^{111}$ に淮じ $\tau 686 \mathrm{~N} / \mathrm{mm}^{2}\left(=7000 \mathrm{kgf} / \mathrm{cm}^{2}\right)$ を上限とした。

式(16)内の変数は, 対象となる拘束域の外周部に配されている横 補強材の寸法を入力し，式(15)に扔いて๙ににそれぞれの拘束域の面 積比 $\alpha i$ 乗じたものを合算した。つまり図7に示すように，範囲1を 対象とする場合のdi'”梳鋼板の厚さspt のdi”'帯筋の直径とした。中子筋と鋼板で拘束されたBタイプのよ うな配筋形式だと四隅の主筋には直接帯筋が配されていないため, 横補強材の有効横支持長さ $(C)$ が大きくなり, 計算上は拘束効果が小

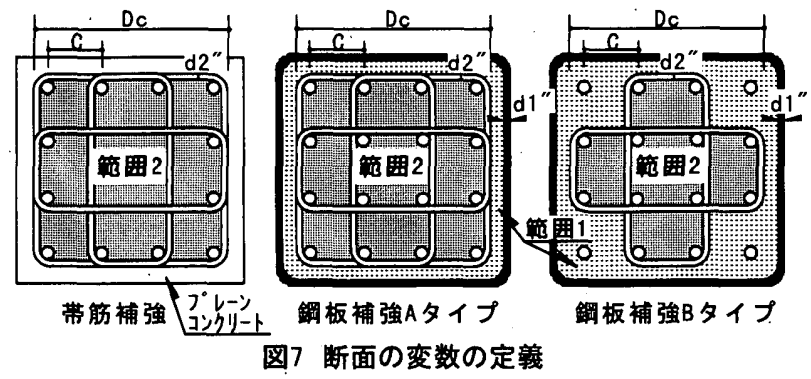

さくなる。しかし，先に述べたように，Bタイプの配智形式がAタイ プと比較して不利にならない( ${ }^{17)}$ と判断し，C值は他の配筋形式と同 様に隣り合う主筋の中心間距離とした。 $s / D c$ は範囲1を対象とする 場合は外周部の横補強材が鋼板であるので零とし, 範囲 2 を対象とす る場合はsが帯筋の間隔, Dcが外周帯筋の中心間距離であるとした。

なお，文献 ${ }^{14)}$ では軸方向力が増大するにつれ，計算値が実験值を 過小評価する傾向があるとし，軸力比による補正值を曲げ終局耐力 計算值に乗じているが，ここでは設計式として安全側の評価を与え るため軸力比による補正は行っていない。

\section{4 終局耐力の実験值と計算値の比較}

曲げ機構を成立させるために必要な主筋の設計用付着応力度 $\tau f$ に対する付着強度 $\tau b u$ の余裕度 (以下, 付着余裕度)を算定し，この 付着余裕度が1.0以上であれば，曲げ機構を成立させるための主筋の 付着強度が確保されているとして，部材のせん断終局耐力，および 曲げ終局耐力の算定を行う。また，付着余裕度が1.0未満の場合は， 部材のせん断終局耐力, 付着割裂強度時せん断力, および曲げ終局 耐力の算定を行う。これらの手順により，部材の破壊形式を想定し， それに対応した終局耐力を算出することが可能である。これらを整 理すると，部材の終局耐力は式(19)拉よび(20)から算出される。

$$
\begin{aligned}
& \tau_{b u} / \tau_{f}<1 \text { 時 } \\
& { }_{c} Q_{\max }=\operatorname{MIN}\left\{\begin{array}{c}
{ }_{c} Q_{m u} \\
\operatorname{MAX}\left({ }_{c} Q_{s c},{ }_{c} Q_{s u A}\right) \\
\operatorname{MAX}\left({ }_{c} Q_{s c},{ }_{c} Q_{b u}\right)
\end{array}\right\} \\
& \tau_{b u} / \tau_{f} \geqq 1 \text { の時 } \\
& { }_{c} Q_{\max }=\operatorname{MIN}\left\{\begin{array}{c}
{ }_{c} Q_{m u} \\
\operatorname{MAX}\left({ }_{c} Q_{s c},{ }_{c} Q_{s u A}\right)
\end{array}\right\} .
\end{aligned}
$$

ここで, $c Q_{m u}$ ：曲げ終局時せん断力 $(\mathrm{N})$ である。

本実験の結果と併せて, 既往の研究 ${ }^{3)}$ 4), 18) 21)の中から外周部を 鋼板補強された試験体のデータベースを作成し各試験体の終局耐力 の評価を行った。試験体の抽出条件は以下の通りである。

\begin{tabular}{|c|c|c|}
\hline コンクリート断面 & $b \times D$ & $300 \times 300 \sim 400 \times 400(\mathrm{~mm})$ \\
\hline 内法スパン長 & $L$ & $750 \sim 1200(\mathrm{~mm})$ \\
\hline コンクリート圧縮強度 & ${ }_{c} \sigma_{B}$ & $20.9 \sim 117.4\left(\mathrm{~N} / \mathrm{mm}^{2}\right)$ \\
\hline 軸力比 & $\eta$ & $0.20 \sim 0.70$ \\
\hline 主筋径(公称値) & ${ }_{m} d$ & $13 \sim 19(\mathrm{~mm})$ \\
\hline 主笳降伏強度 & ${ }_{m} \sigma_{y}$ & $361 \sim 738\left(\mathrm{~N} / \mathrm{mm}^{2}\right)$ \\
\hline 軸鉄筋比 & $p_{g}$ & $2.15 \sim 3.19(\%)$ \\
\hline 帯筋径(公称値) & ${ }_{w} d$ & $6 \sim 10(\mathrm{~mm})$ \\
\hline 帯筋降伏強度 & ${ }_{w} \sigma_{y}$ & $341 \sim 1284\left(\mathrm{~N} / \mathrm{mm}^{2}\right)$ \\
\hline 帯筋比 & $p_{w}$ & $0.11 \sim 1.43(\%)$ \\
\hline 補強鋼板厚さ & ${ }_{s p} t$ & 無し〜9 mm \\
\hline 補強鋼板の降伏強度 & $s p \sigma_{y}$ & $165 \sim 436\left(\mathrm{~N} / \mathrm{mm}^{2}\right)$ \\
\hline
\end{tabular}

○部材断面が $300 \times 300 \mathrm{~mm}$ 以上の矩形断面であり, 部材の外周部 を鋼板で補強されたRC造の試験体。ただし，比較のために同 ーシリーズで実施された帯筋補強試験体は含む。

○実験時最大耐力, および計算耐力を算出する上で必要な情報 が記述されている文献の試験体。

○耐震改修等を目的とし鋼板と躯体の間にグラウトが充填され たり，仕上げを意図したモルタル等が含まれた試験体は除外。 

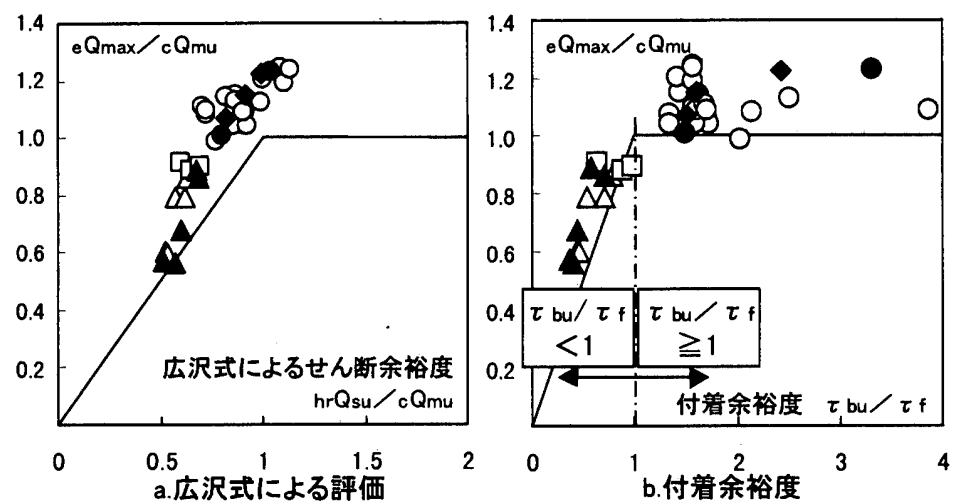

図8 終局耐力の実験值と計算值の比較

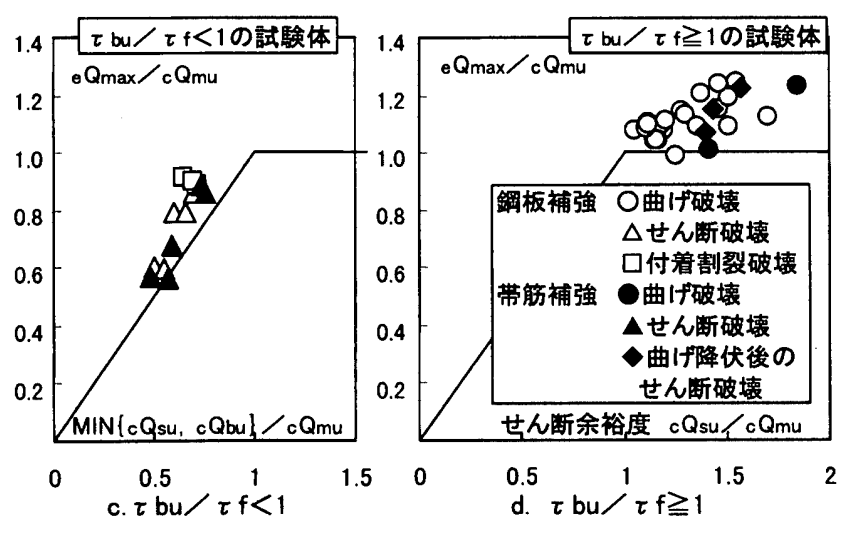

のトラス機構負担率 $(\beta)$ は 1.0 となるため, ア一チ機構負担せん断力 は零となる。そこで前述の通り, 鋼板補強試験体のコンクリートの 損傷が極めて軽微であったことを考慮し，鋼板補強された柱におい て曲げ降伏を先行させる場合のせん断終局耐力は $\nu=\nu_{0}$ とし, 第1 項に $R_{p}$ の関数である低減係数 $\xi$ 垂じる形で表す。

$$
\begin{aligned}
& { }_{c} Q_{s u A}=\xi \cdot b \cdot j_{t} \cdot \Sigma\left(p_{x} \cdot{ }_{x} \sigma_{y}\right) \cdot \cot \phi \\
& +\tan \theta \cdot(1-\beta) \cdot b \cdot D \cdot v_{0}{ }_{c} \sigma_{B} / 2 \\
& \cot \phi=\operatorname{MIN}\left\{2.0, j_{t} / D \cdot \tan \theta, \sqrt{v_{0}{ }_{c} \sigma_{B} / \Sigma\left(p_{x}{ }_{x} \sigma_{y}\right)-1}\right\} \\
& \beta=\left\{\left(1+\cot ^{2} \phi\right) \cdot \Sigma\left(p_{x} \cdot{ }_{x} \sigma_{y}\right)\right\} /\left(v_{0}{ }_{c} \sigma_{B}\right) \\
& \Sigma\left(p_{x}{ }_{x} \sigma_{y}\right)=p_{w}{ }^{\prime} \sigma_{y}+p_{s p}{ }_{s p} \sigma_{y} \leqq v_{0}{ }_{c} \sigma_{B} / 2 \quad\left(\mathrm{~N} / \mathrm{mm}^{2}\right)
\end{aligned}
$$

図9にQ-R関係の模式図を示す。最大耐力後のせん断力が最大耐 力の0.8倍まで低下した点をせん断破壊による限界変形角 $(s R u)$ とし たとき，限界変形角時に曲代耐力計算值と等しいせん断力を保持す ることができれば，目標とする変形角が保証されることとなる。つ まり,式(21)のc $Q_{s u A}$ に曲げ終局時せん断力の計算值 $(c Q m u)$ を代入し逆 算すれば限界変形角時の低減係数 のデーターベースに示した試験体の実験結果よりをの算出を試みた。

図10に $\xi$ と限界変形角時ヒンジ部回転角 $\left(R_{p}\right)$ の比較を示す。ここ で限界変形角 $\left(s R_{u}\right)$ は最大耐力からその $80 \%$ まで耐力が低下したとき の水平部材角とし, 横軸の $R_{p}$ は式(25)に示すように, 実験値の $R_{s u}$ か ら降伏時変形角 $\left(R_{y}\right)$ の計算値を引いた值とした。

$$
\begin{aligned}
R_{p} & ={ }_{s} R_{u}-R_{y} \\
& ={ }_{s} R_{u}-{ }_{c} Q_{m u} /\left(\alpha_{y} \cdot K_{e}\right)
\end{aligned}
$$

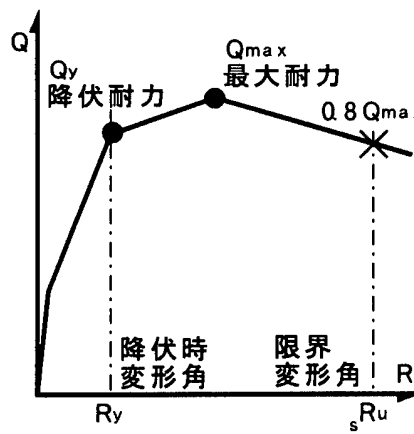

a.実験結果の模式図

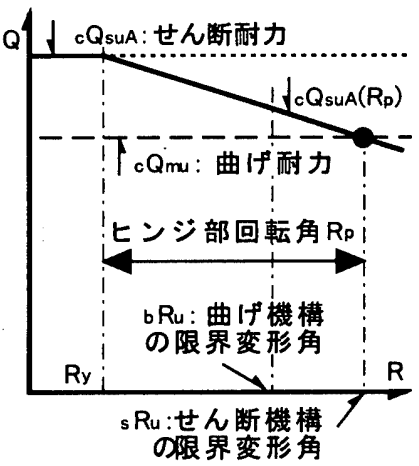

b.終局耐力と変形角の関係
図9Q-R関係の模式図 


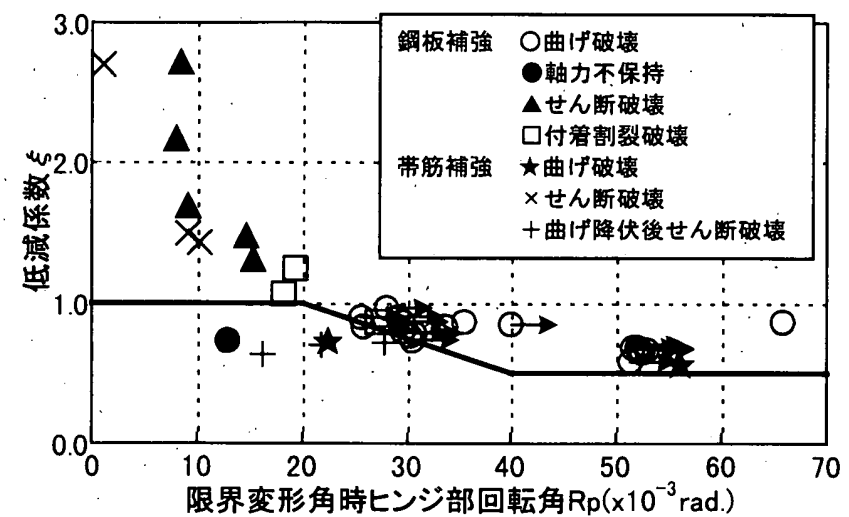

図10 限界变形角時ヒンジ部回転角 $\left(R_{p}\right)$ と低減係数 $\xi$ の関係

$$
\begin{aligned}
& \alpha_{y}=\left(-0.0836+0.159 \cdot \frac{a}{D}+0.169 \cdot \eta\right) \cdot\left(\frac{d}{D}\right)^{2} \quad(a / D<2.0)^{22)} \\
& \text { ここで, } K_{e}: \text { 弾性剛性 }(\mathrm{N} / \mathrm{rad} .), \eta \quad \eta \text { 軸力比である。 }
\end{aligned}
$$

图10にプロットした破壊形式は，各文献に示された記述に基づい ている。ここに示した鋼板補強試験体の中には曲げ降伏後のせん断 破壊によって限界変形角に達した試験体は無い。図10より曲げ圧縮 破壊によって軸力が保持されなかった試験体と帯筋補強試験体を除 き, 実験值の概悋下限值の直線を引くとせん断耐力低減係数 (27)で表される。

$$
\xi= \begin{cases}1.0 & 0<R_{p} \leqq 0.02 \\ \left(3-50 R_{p}\right) / 2 & 0.02<R_{p} \leqq 0.04 \\ 0.5 & 0.04<R_{p}\end{cases}
$$

\section{2 曲げ機構の限界变形角}

一定軸力下のRC柱を対象とし, 曲げ庄縮破壊によって最大耐力の $95 \%$ まで耐力低下する点を曲げ機構の限界変形角 $(b R u)$ として, 稲 井・平石らは式(28)に示す算定式を提案している ${ }^{23)}$ 。

$$
\begin{aligned}
{ }_{b} R_{u} & =(1-2 \eta) / 14 \quad\left({ }_{b} R_{u} \leq 0.06\right) \\
\eta & =\left(N_{\exp }-N_{s}\right) /\left(b^{\prime} \cdot D^{\prime} \cdot f_{c}{ }^{\prime}\right) \\
f_{c}{ }^{\prime} & =K \cdot{ }_{c} \sigma_{B}
\end{aligned}
$$

ここで， $N$ exp : 載荷軸力 $(\mathrm{N}), N_{s}$ : 断面せいの中間部 $D / 3$ 間に含ま れる主筋の負担軸力 $(\mathrm{N}), b^{\prime} \cdot D^{\prime}:$ 帯筋補強柱は帯筋の中心線で囲ま れた面積 $\left(\mathrm{mm}^{2}\right)$, 鋼板補強柱は鋼板で囲まれた面積 $\left(\mathrm{mm}^{2}\right)$ である。

式(28)は，主に，帯筋を使用したRC柱を対象とし，コアの断面積 とその圧縮強度によって, 限界変形角が定まるとしている。崎野ら によれば，直線型横補強材によって拘束されたコンクリートの圧縮 特性は，鋼管，帯筋等の拘束材料の違いに関係なく同じ基準で評価 できるとしている ${ }^{15)}$ 。よって，式(29)においてコア面積である $b^{\prime} \cdot D^{\prime}$ に鋼板で囲まれた面積を代入することによって，鋼板補強された部 材に対しても式(28)を適用することが可能であると考えられる。な お，コア部分の圧縮強度 $\left(f_{c}{ }^{\prime}\right)$ は式(15)から得られる拘束コンクリート の強度上昇率Kから算出される。

\section{5. 横補強材による拘束効果を考慮したせん断カー水平部材角関係の モデル化}

\section{1 曲げ降伏型の包絡線}

鋼板等によって横拘束された柱部材のせん断力一水平部材角関倸 の包絡線を図11に示す3折れ線でモデル化する。ここで, 第1折れ点 は曲げひび割れ点，第2折れ点は部材の曲げ降伏点とする。

まず, 第1折れ点は, 曲げひび割れ耐力計算式と弾性剛性から算出 される。ここでは，曲げひび割れ耐力および弾性剛性には横補強材 による拘束効果の影響がないとし, 通常のRC部材と同様に算出され る。次に第2折れ点の曲げ降伏耐力は, 前述の崎野・孫が提案してい る等価応力ブロックを用いた計算法により算出する。また本実験の 結果より，曲げひび割れ以降の剛性低下率に関しては横補強材の種 類による影響はないとして, 降伏時変形角は式(26)に示した剛性低 下率 $\alpha y^{22)}$ から算出する。

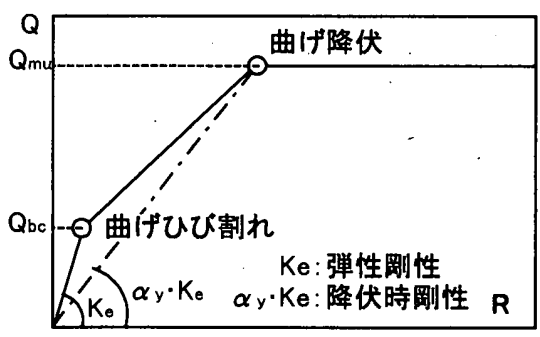

図11曲げ降伏型の包絡線

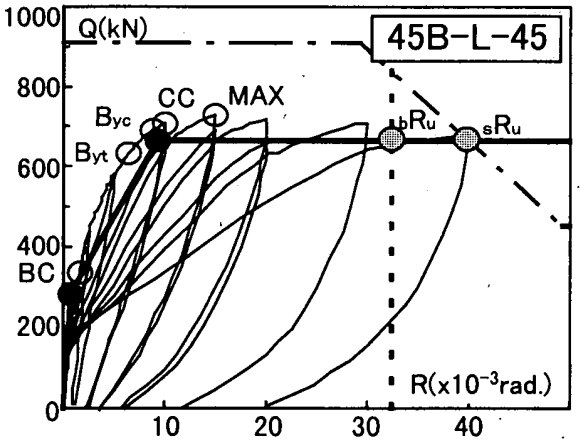

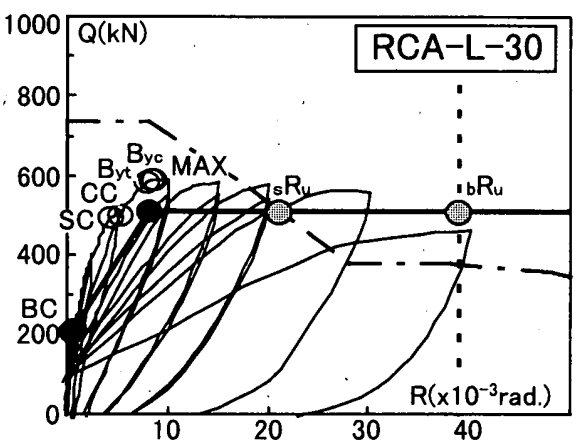
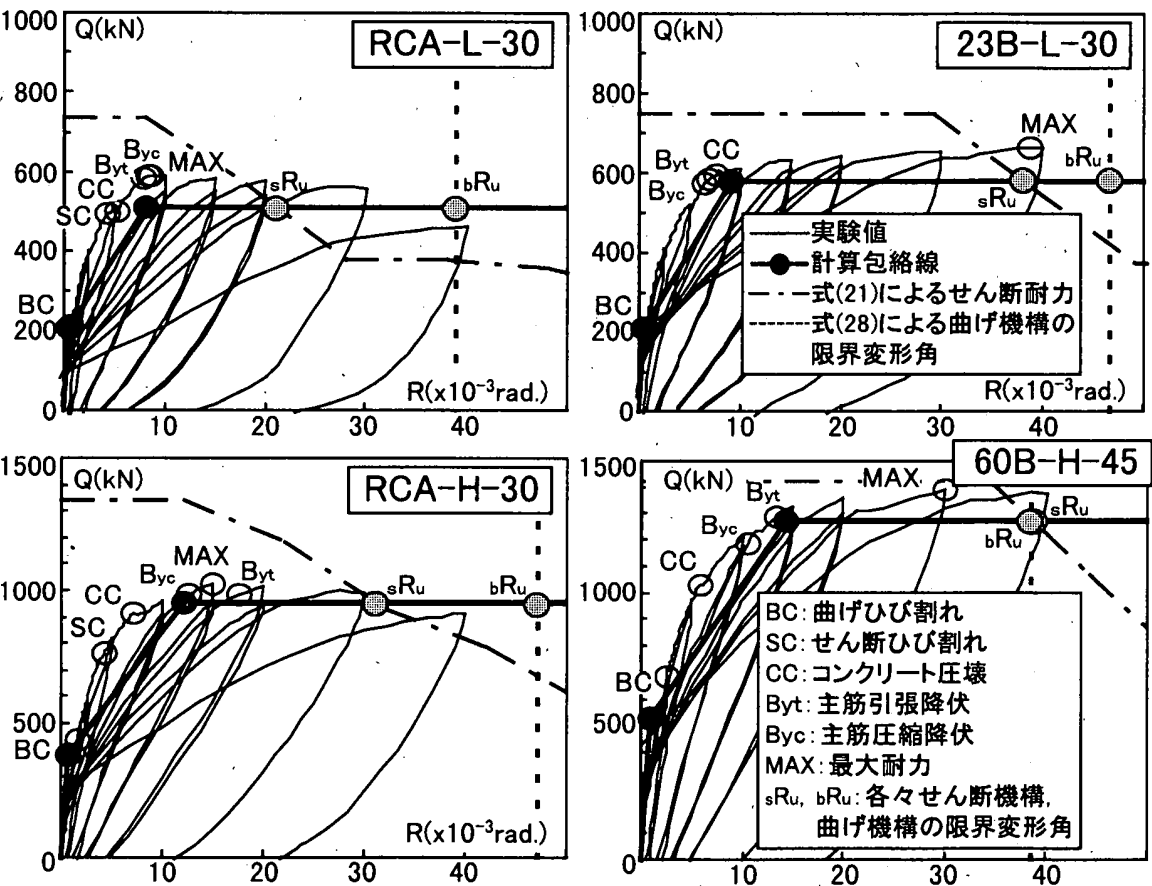

図12 せん断カー水平部材角関係の実験値と計算值の比較 


\section{2 実験値亡計算值の比較}

图12にせん断力 $(Q)$ - 水平部材角 $(R)$ 関係の実験值と, 計算值のス ケルトンカーブの比較を示す。ここで，太実線は曲げ降伏型の包絡 線であり，一点鎖線は式(21)から得られた降伏ヒンジ部の回転角を 考慮したせん断耐力である。また，破線は式(28)から得られた曲げ 機構の限界変形角である。これによると，本論で示した計算方法に よって, 初期剛性から部材の降伏に至るまでのせん断力一水平部材 角関係の実験值を精度良く再現することが可能であり，また，せん 断機構による限界変形角, および曲げ機構による限界変形角によっ て, 変形能の限界点が安全側に評価された。

ここで注意すべき点は，一般的に曲げ機構の限界変形角は最大耐 力から95\%まで低下した時の水平部材角であり，せん断機構の限界 変形角は同じく $80 \%$ まで低下した時の水平部材角と定義されること が多く，両者の数值に差があることである。これらを比較すると， 曲げ機構による限界変形角の方が数字上は厳しいように思われる。 しかし部材の限界変形角が曲げ機構による限界変形角で定まる場合 は，主に軸力比が高い場合であり，限界変形角後に急激な軸方向力 の衰失が予想される。よって，両者で部材の崩壊に対する安全率が 異なっているが，本論では二つを比較して小さい方の変形角を部材 の限界変形角とした。

なお，本研究ではせん断スパン比が1.0以下の部材に対しては，鋼 板によるせん断補強効果を検証していない。このような極短柱 ${ }^{24)} に$ 対する鋼板のせん断補強効果については今後の検討課題である。

\section{6. 結論}

鋼板補強された柱部材の試験体を製作し, 曲げ破壊, せん断破壊, および付着割裂破壊させた実験を実施した。その実験結果を基に考 察を行い，以下に示す結論が得られた。

（1）曲げ降伏前における鋼板補強試験体のせん断終局耐力は鋼板を 横補強筋量の和 $\left(p_{w^{*}} w \sigma y+p_{s p} \cdot s p \sigma y\right)$ に換算することで带笳補強試 験体と同様に評価できた。

（2）柱断面の四隅に配された隅主笳にかかる外周帯筋を省略した鋼 板補強試験体(Bタイプ)は，鋼板の効果を考慮した付着設計を行 うこ・とにより，主筋の降伏以降も付着劣化は認められず，横補強 筋量の和が等しい囲形に配筋された試験体(Aタイプ)との構造的 な差異は無かった。

（3）曲げ降伏が先行する場合，鋼板補強試験体は横補強筋量の和が 等しい帯筋補強試験体と比較して大変形時の部材の損傷が極め て少なく, 耐力低下もほとんど無かった。その特性を基に降伏七 ンジの回転角を考慮したせん断耐力低减係数を提案した。

(4) 既往の研究から鋼板補強された柱試験体および比較用の帯筋補 強試験体を抽出し, 本論で示した実験結果と併せて終局耐力の評 価を行った。それらは, 鋼板の効果を考慮した付着割裂強度算定 式, せん断終局耐力計算式および既往の曲げ耐力計算法によって, 各破壊モードに対応した終局耐力の評価が可能であった。また， 帯筋に拘束される領域と鋼板に拘束される領域を定義すること によって, 帯筋の配筋形状が異なる場合でもその曲げ終局耐力を 評価できた。

（5）鋼板補強された部材の復元力特性は，通常のRC部材に対する計 算法を用いた初期剛性, 剛性低下率扝よび前述の曲げ終局耐力計
算法により精度良く評価できた。限界変形角は曲げ機構によるも のとせん断機構によるものがあり,これらによって決定される包 絡線は実験結果を安全側に評価した。

\section{参考文献}

1)鈴木英之，西原寛：鋼板等により横拘束された鉄筋コンクリート造柱の構造性能， 日本建筑学会大会学術講演梗概集，C-2，pp.481-482，2001.9

2)舒木英之, 西原寬: 鋼板等により横拘束された鉄筋コンクリート造柱の構造性能(そ の2)，日本建築学会大会学術講演梗概集，C-2,pp.443-444，2002.8

3)㴊川正四郎, 中出睦他: 高軸力を受ける鋼板拘束RC柱の構造性能に関する実験的 研究(そのI〜2), 日本建筑学会大会学術講演梗概集, C-2, pp.455-458, 1998.9

4)山内茂一, 稲永英治他 : 超高強度材料を用いた鉄筋コンクリート造の柱部材に関す る実験研究（その3 4), 日本建築学会大会学術講演梗概集，pp.191-194，2000.9

5) 日本建築防災協会: 2001 年改訂版既存鉄筇コンクリート造建築物の耐震改修設計指 針同解説，2001.10

6)鈴木英之，西原寛，田畑卓 : 鋼板補強された鉄筋コンクリート部材の付着割裂強度， コンクリート工学年次論文集，第23巻第3号，pp.835-840，2001.6

7)益尾絜，平井義行他：鋼板補強およびカーボン綀維補強による鉄筋コンクリート柱 の王縮勒性の改善効果に関する㬰験，GBRC, vol.86, pp.50-62，1997.4

8)益尾潔, 井上挈也他 : 既存RC柱の鋼板補强およU゙CFRP補强の効果に及ほす寸仕上げ モルタルの影響に関する実駼，GBRC，vol.92，pp13-24，1998.10

9)藤井栄，森田司郎，川上修司，山田稔明 : $90^{\circ}$ 折り曲げ鉄筋の定着耐力の再評価, 日本建筑学会構造系論文報告集，第429号，pp.65-75，1991.11

10) 日本建築学会 : 鉄筋コンクリート造建物の終局強度型耐震設計指針・解祱, 1990.11 11)(財)国土開発技術センター: 平成4年度New RC研究開発概要報告書, 1993.3

12)横尾慎一, 市之瀬敏勝 : RC部材のせん断設計法への一提案, 日本建築学会大会学 術講演梗概集，C，pp.283-284，1991.9

13)角徹三，山田守，合楽将三 : 鉄筋コンクリートはりの付着割裂强度に及ぼす横補 強筋の効果，コンクリート工学年次論文報告集，Vol.11，No.2，pp.177-182，1989.6 14)棌玉平，崎野健诒，池之野陽一：拘束正方形RC柱の曲げ終局耐力およひ変形につ いて(その1〜2), 日本建築学会大会学術䢂演梗概集, C-2, pp.325-328, 1998.9 15)崎野健治, 棌玉平 : 直線型横補强材により拘束されたコンクリートの応力ーひず み関係，日本建築学会構造系論文集，第461号，pp.95-104，1994.7

16)山川哲雄，崎野健治 : 正方形銅管と带筋で二重に横拘束したコンクリートの中心 圧縮性状に関する実験的研究，コンクリート工学年次論文報告集, Vol.14, No.2, pp.345-350, 1992.6

17)山川哲雄 : 正方形鋼管と直線型帯筋で二重に横拘束したコンクリートの王縮性状 に関する実験的研究，コンクリート工学年次論文報告集，Vol.15, №.2, pp.537-542, 1993.6

18)森浩二，中沢敏樹，佐藤尚隆 : 炭素結維シートおよび鋼板により補強された铁筋 コンクリート柱のせん断而付に関する夷験(その1〜2), 日本建築学会大会学術講演 梗概集，C-2，pp.661-664，1997.9

19)益尾潔，井上寿也，上田実香他：高軸力下のRC柱に対する鋼板およびカーボン樴 維の補強効果(その1〜2), 日本建築学会大会学術講演梗概集，C-2, pp.257-260, 1998.9

20)藤田将辉，松崎育弘，中野克彦他：鉄朌コンクリート柱部材の強度と勒性能に関 する実験的研究，日本建築学会大会学術講演梗概集，C-2，pp.797-798，1999.9

21)古川淳, 花井伸明他 : 鎙板と帯筋で二重補強したRC柱の変形能に関する実験的研 究(その1〜2), 日本建築学会大会学術講演梗概集，C-2, pp.445-448，2002.8

22)菅野俊介, 東端泰夫, 山口㕕雄 : 鉄筋コンクリート短柱の崩填防止に関する総合 的研究(その18), 日本建築学会大会学術丵演梗概集, 構造系, pp.1323-1324, 1974.10

23)稲并栄一，平石久廣，薬研地彰：一定軸力下で曲け破壊する鉄筋コンクリート造 柱の設計用限界変形算定式，日本建築学会構造系論文集，第536号，pp.129-134， 2000.10

24)日本建筑防災協会 : 2001 年改訂版既存鉄筋コンクリート造建築物の耐展診断基蕉 同解説，2001.10

（2003年 2 月 6 日原稿受理， 2003 年 7 月 8 日採用決定） 